\title{
Fibrotic Stroma Formation
}

National Cancer Institute

\section{Source}

National Cancer Institute. Fibrotic Stroma Formation. NCI Thesaurus. Code C36178.

A morphologic finding that indicates the presence of reactive fibrotic stroma in a tissue sample. 